\title{
Trends of hepatitis B notification rates in Turkey, 1990
} to 2012

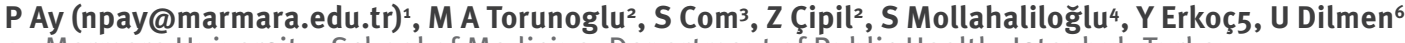

1. Marmara University, School of Medicine, Department of Public Health, Istanbul, Turkey

2. Turkish Public Health Institution, Ministry of Health, Ankara, Turkey

3. Provincial Health Directorate, Ministry of Health, Ankara, Turkey

4. Health Politics Board, Ministry of Health, Ankara, Turkey

5. Ministry of Health, Ankara, Turkey

6. General Directorate of Health Research, Ministry of Health, Ankara, Turkey

Citation style for this article:

Ay P, Torunoglu MA, Com S, Cipil Z, Mollahaliloğlu S, Erkoç Y, Dilmen U. Trends of hepatitis B notification rates in Turkey, 1990 to 2012. Euro Surveill.

2013;18(47):pii=20636. Available online: http://www.eurosurveillance.org/ViewArticle.aspx?Articleld=20636

Article submitted on 17 November 2012 / published on 21 November 2013

Turkey is a country with intermediate endemicity for hepatitis $B$, and approximately $4 \%$ of the population are HBsAg-positive. A number of measures have been implemented to prevent hepatitis B infection. In 1998, hepatitis $B$ antigen was included in the national immunisation programme, and infants have since been vaccinated with three doses. Catch-up strategies, vaccination for high risk groups and screening measures were also adopted. The aim of this study was to evaluate the impact of the prevention and control strategies on hepatitis B notification rates in Turkey in the period from 1990 to 2012 , using data from the national surveillance system. Secular trends revealed that rates showed an initial increasing trend, followed by a steady decline from 2005. The most dramatic decline occurred among children younger than 15 years, highlighting the benefits of vaccination and catch-up strategies. However, vaccination cannot fully explain the decrease in this age group. Socioeconomic development, through interrupting the horizontal transmission may also have contributed. After 2005, a steady decline was achieved also among those 15 years and older. The rates in adults were higher, which indicates that stronger prevention measures are needed to target this group, particularly men.

\section{Introduction}

It is estimated that approximately 2 billion people in the world have been infected with hepatitis $B$ virus (HBV) $[1,2]$. Among those, 360 million are chronic carriers and have a $15 \%$ to $25 \%$ risk of premature death from consequences such as liver cirrhosis and hepatocellular cancer $[1,3]$. The burden of hepatitis B differs worldwide. Countries in eastern and southern Europe have a moderate prevalence of chronic hepatitis, and Turkey is classified as a country of intermediate endemicity with approximately $4 \%$ of the population HBsAg-positive [2,4]. In a meta-analysis, evaluating seroprevalence studies published between 1999 and
2009, it was determined that the overall HBsAg positivity in Turkey was $4.6 \%$ [5].

Rates of HBsAg positivity vary within Turkey. Seroepidemiological studies show a decreasing trend from south-east to west in all age groups [5-12]. In a meta-analysis evaluating studies published between 1999 and 2009, Toy et al. estimated that the prevalence rates of HBsAg positivity in the west, middle and eastern regions were $3.5 \%, 4.9 \%$ and $6.8 \%$, respectively. In the same study, the authors concluded that the lowest prevalence was in children who were younger than 15 years $(2.8 \%)$ and the highest prevalence was among 25-34 year-olds (6.4\%) [5].

In Turkey, hepatitis B vaccine has been on the market since the late 1980s, yet a systematic vaccination policy was not adopted at that time [13]. Since 1998, when hepatitis $B$ antigen was included in the national immunisation programme, infants have been vaccinated with three consecutive doses. Although there have been some changes regarding vaccination schedules, infants have since 2003 received the antigen within the first $72 \mathrm{~h}$ after birth, followed by two additional doses at the end of the first and the sixth month of age. Catch-up strategies targeting older age groups are also used as a supplement to routine infant vaccination because studies among children six to 17 years of age, carried out in different parts of the country, indicate a gradual increase in the seroprevalence with rising age $[4,10-12,14]$. This finding suggests that horizontal transmission, through close contact with infected family members, is the main mode of transmission among children $[4,10,14-16]$. Vaccination activities were therefore carried out in primary schools during the period 2005 to 2009. In Turkey, eight years of primary schooling is mandatory and children start school at the age of six years. Target age groups which were included in catch-up vaccinations are presented in the Table. In 
TABLE

Target age groups for catch-up vaccinations by school year, Turkey, 2005-2009

\begin{tabular}{|l|l|}
\hline School year & \multicolumn{1}{|c|}{ Target group } \\
\hline 2005-06 & $\begin{array}{l}\text { Primary school students at the eighth grade (13 } \\
\text { years-old) }\end{array}$ \\
\hline 2006-07 & $\begin{array}{l}\text { Primary school students at the sixth, seventh } \\
\text { and eighth grades (11, 12 and 13 years-old) }\end{array}$ \\
\hline 2007-08 & $\begin{array}{l}\text { Primary school students at the third, fourth, } \\
\text { fifth, and sixth grades (8, 9, 10 and 11 years-old) }\end{array}$ \\
\hline 2008-09 & $\begin{array}{l}\text { High school students at the fourth grade (17 } \\
\text { years-old) }\end{array}$ \\
\hline
\end{tabular}

Turkey, vaccination policies are adopted at the national level and are the same in all geographic regions.

Also high-risk groups for contracting hepatitis B have been vaccinated free-of-charge since 1998, namely healthcare workers, people who inject drugs, persons with high-risk sexual behaviour, persons who frequently require blood or blood products, haemodialysis patients, close contacts of HBsAg-positive persons, persons residing in orphanages, detention centres and prisons.

Strategies for screening were also adapted. In Turkey, it has been mandatory since 1993 to screen all voluntary blood donations for HBV. All registered sex workers are tested for hepatitis B every three months. Since sex workers are categorised as a high-risk group, vaccinations are offered free of charge. Screening is also carried out when an unregistered sex worker is arrested by the police. Since 2002, couples who appeal for marriage are asked whether they have hepatitis $B$ infection, and counselling is provided, but laboratory analysis is carried out only among the ones who meet the definition of high risk as presented above. Vaccinations are offered to people testing negative. Antenatal screening for HBsAg among pregnant women is not mandatory. Condom use is promoted as a preventive strategy. In Turkey, condoms are freely available at the primary level of care. Advertisements on visual and written media are used for raising awareness about prevention measures.

The aim of this study was to evaluate the impact of the above prevention and control strategies on acute hepatitis B notification rates in Turkey. The main goal was to assess the trend in acute hepatitis $B$ notifications from 1990 to 2012, in order to address future prevention and control activities.

\section{Methods}

In this study, data obtained from the National Surveillance System (NSS) were used for evaluating acute hepatitis $B$ notification rates. In Turkey, acute hepatitis B has been notifiable since 1990 , and data were collected on a monthly basis by sex, age and province. However, a national guideline encompassing standard case definitions was not in use at that time. In 2004, the Turkish Ministry of Health updated the NSS and introduced standard case definitions for each notifiable disease. According to the newly launched definitions, patients compatible with the clinical picture and positive for anti-HBc IgM and/or $\mathrm{HBsAg}$, were identified as acute hepatitis B cases [17]. Notification was restricted to acute cases. Practically, the newly launched case definition for acute hepatitis B did not differ from the criteria used for acute infections before 2004 in clinical practice. But this was the first time a standard case definition was adopted and circulated to all healthcare institutions throughout the country. Training programmes for physicians were implemented, introducing the case definitions and also emphasising the importance of surveillance.

Notification rates were calculated per 100,000 population. Age groups were defined as $0,1-4,5-9,10-14$ and $\geq 15$ years. For calculating regional rates, the Nomenclature of Territorial Units for Statistics (NUTS) was used and provinces were categorised in 12 territorial units [18].

In Turkey, healthcare providers report the number of vaccinated children on a monthly basis to the Ministry of Health through the district and provincial health authorities. Reporting has been carried out electronically since 2011. Hepatitis B vaccination coverage refers to the percentage of fully vaccinated children reaching their first birthday. An infant that has received three doses of hepatitis B vaccine is defined as fully vaccinated. In this study, vaccine coverage data were obtained from the Ministry of Health.

\section{Results}

Acute hepatitis B notification rates between 1990 and 2012 are presented in Figure 1. In 1990, the notification rate was 4.8 per 100,000 population. Rates showed an increasing trend and reached 12.3 per 100,000 in 2005. After 2005 , there was a steady decline, and the rates in 2011 and 2012 dropped to 3.9 and 3.6 per 100,000, respectively (Figure 1). Vaccine coverage rates between 1999 and 2012 are also presented in Figure 1. In 1999, $64 \%$ of infants had been vaccinated with three doses of hepatitis B antigen. Coverage showed an increasing trend and rates above $90 \%$ were maintained after 2006 (Figure 1).

Notification rates by age groups are presented in Figure 2. Notification rates in 1997 for children aged «1 year, 1-4 years, 5-9 years and 10-14 years were 8.19, $5.21,9.54$ and 8.74 per 100,000 , respectively. Rates for children under the age of 15 years showed a decreasing trend until 2004. In 2001 and 2005 there were small peaks among those younger than 15 years. However, after 2005 a steady decline was observed in all age groups younger than 15 years. The notification rates 
Notification rates for acute hepatitis B (1990-2012) and percentage of infants vaccinated with three doses of hepatitis B virus antigen (1999-2012), Turkey*

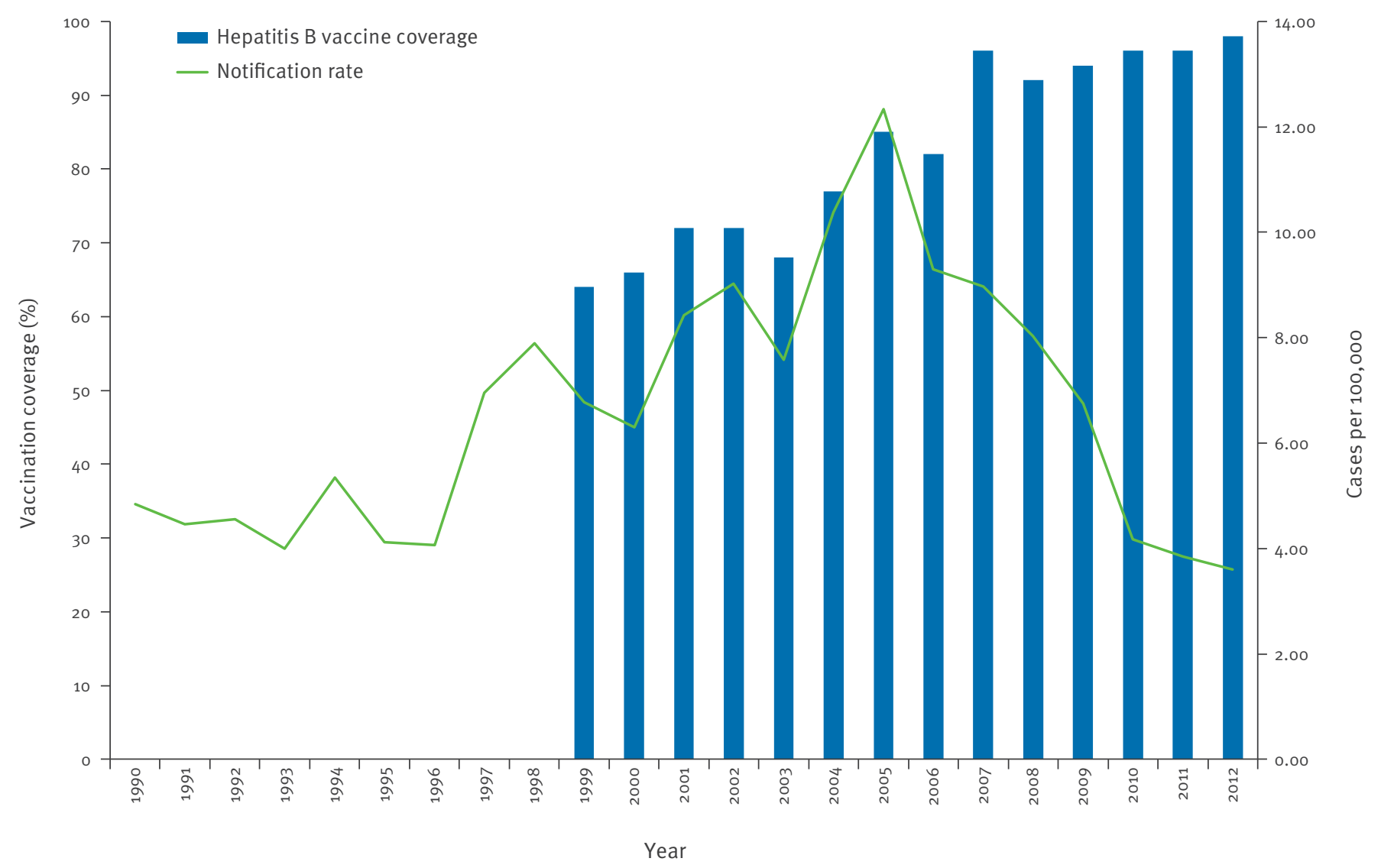

in 2012 for the $1-4,5-9$ and $10-14$ year-olds were 1.8 , $0.2,0.5$ and 0.9 per 100,000, respectively.

Since infant vaccination started in 1998, notification rates for the under five years-old in 2002 and 2003 represent the first results for age groups that received vaccination.

The notification rate for those 15 years and older was 6.45 per 100,000 in 1997 . Unlike the younger population, rates for this age group showed an increasing trend until 2005 and declined thereafter. The rates in 2005 and 2012 were 15.32 and 4.6 per 100,000, respectively.

Notification rates by age and sex for 2012 are presented in Figure 3. Notification rates for males and females in 2012 were 4.6 and 3.6 per 100,000 , respectively. The rates were higher among male than among female infants for 2012, data from previous years showed similar rates (data not shown). Rates were slightly higher among boys during childhood after the first year. Men older than 19 years had higher rates than women. The highest rate difference between men and women was observed in the age group of 30-44 year-olds. Among this age group, the rate difference was 3.3 per 100,000 in 2012.
Notification rates are also analysed by geographical region (Figure 4). Highest rates were observed in Istanbul, west Marmara, northern regions and middle Anatolia. Southern regions had lower rates. Eastern Anatolia showed exceptionally low notification rates. Vaccination rates were similar throughout the country, but lowest rates were observed in the eastern regions.

\section{Discussion}

Notification rates of acute hepatitis $B$ showed a decreasing trend among those younger than 15 years between 1997 and 2004. The most dramatic decline was observed among children under the age of five years, highlighting the benefits of vaccination which had been introduced in 1998. However, in 2001 and 2005 , the downward trend changed and notification rates peaked among children under 15 years of age. The trend change in 2005 could be related to the introduction of the new notification system. In 2004 with the change of the Communicable Disease Notification System, a standard case definition was adopted for acute hepatitis B infection $[19,20]$. Although the newly launched criteria were not different from those used in daily practice before, revisions may have created awareness among health personnel and led to an increase in notification rates. After 2005 and until 


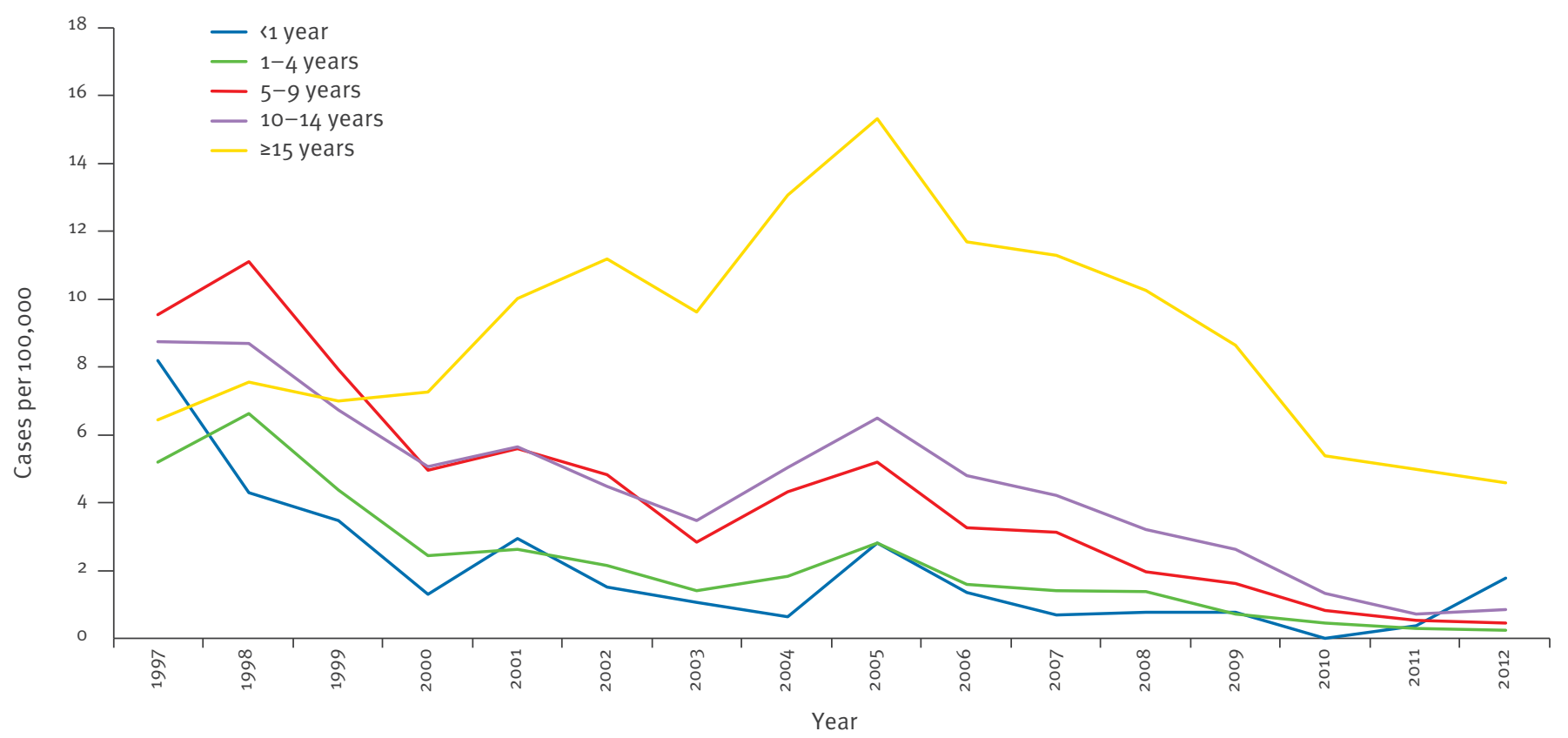

2012, the rates have been declining steadily among all age groups under 15 years.

The first infant cohort was vaccinated in 1998 as part of the national immunisation programme. This group reached the age of five in 2003 explaining the decrease in the rates for 5-9 year-olds after 2003. Children younger than 15 years had been vaccinated by 2007 through catch-up activities, therefore the decrease after 2007 for children aged 10-15 years was also expected. However, not all the decline can be explained by vaccination activities. Epidemiological studies in Turkey show that HBsAg positivity is more prevalent among socioeconomically disadvantaged groups, and that horizontal transmission is the main route of transmission $[4,9,10,12,14-16,21]$. In a study carried out in one of the hospitals in Turkey during 2001-05, it was determined that HBsAg carrier rate was higher among fathers than among mothers. However, in the present study, it was determined that the children of mother index cases had higher rates of HBsAg compared with the children of father index cases. So in intra-familiar transmission, mother-to-child has been suggested as the main route. Since mothers mostly are not working and spend longer time with their children, their risk of transmitting the virus is higher compared to fathers. [16]. Socioeconomic development, leading to improved living conditions, less crowded families, improved sanitation and hygiene practices could have interrupted intra-familiar transmission and contributed to the decreasing trends [22-25]. A study in Italy showed that the decrease in acute hepatitis B was more apparent before the introduction of the mass immunisation. The authors concluded that the improved socioeconomic

\section{FIGURE 3}

Notification rates for acute hepatitis B by sex and age group, Turkey, 2012

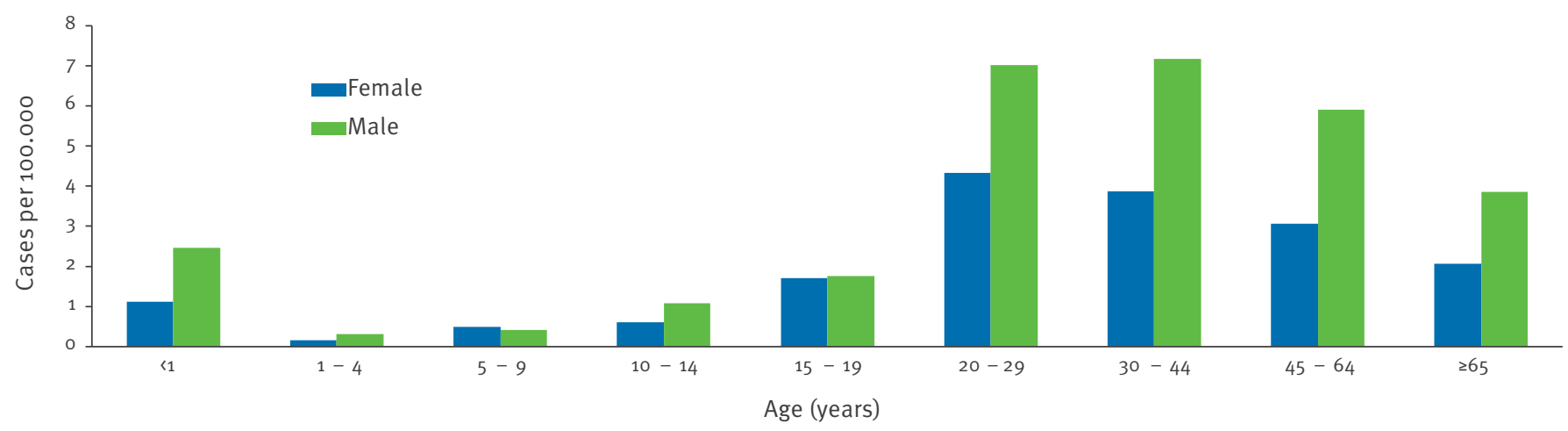


Notification rates for acute hepatitis B cases per 100,000 and percentage of infants vaccinated with three doses of hepatitis B virus antigen, by region, Turkey, 2012

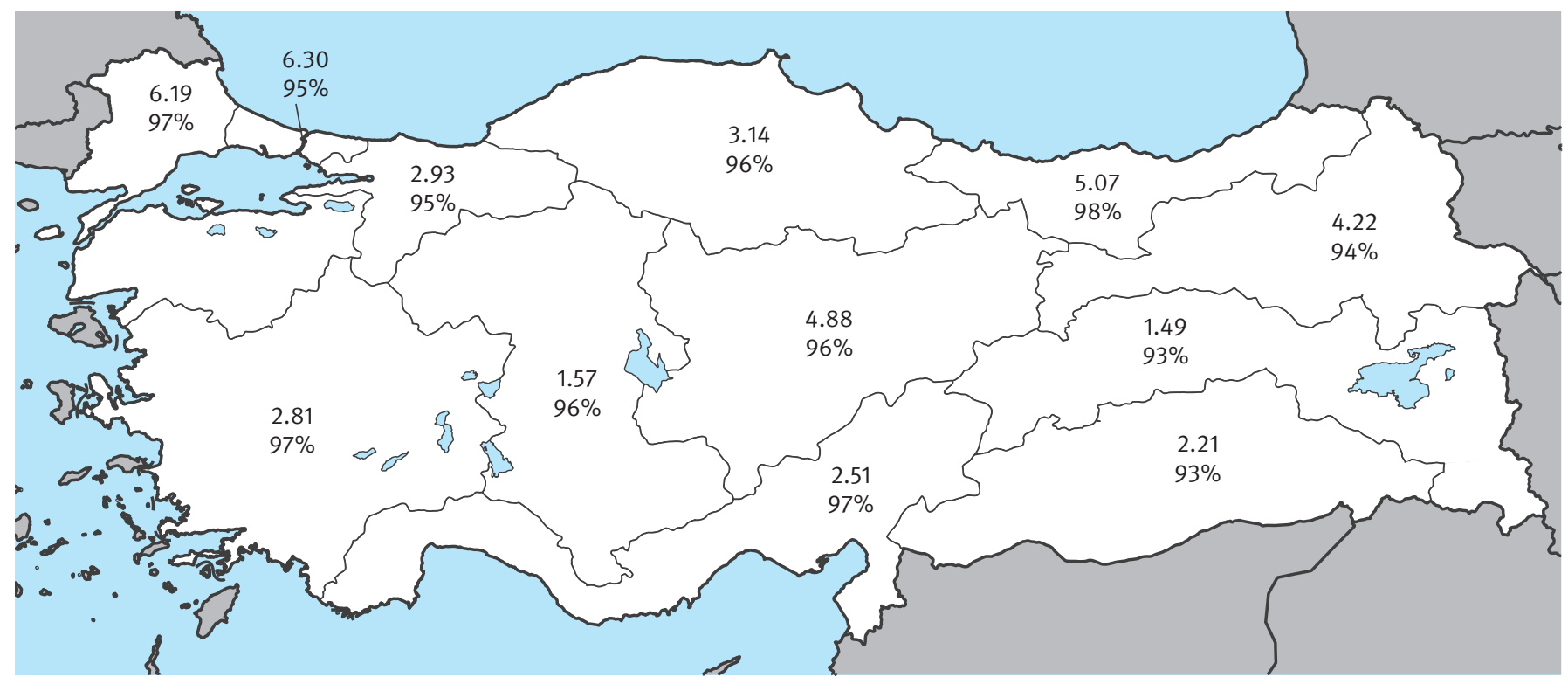

Source: Kartenwerkstatt; http://commons.wikimedia.org

and sanitary conditions in the country had resulted in declining rates [22].

The notification rates for those 15 years and older followed an upward trend until 2005 and a decrease thereafter. Introduction of standard case definitions in 2004 and prevention activities among adults may have had an impact, but are not sufficient to explain the trend change after 2005. There is not any information on the uptake of vaccination outside the national immunisation programme. Still, the continuing downward trend after 2005 suggests that there is a true reduction in hepatitis $B$ infections also among this age group.

Adults still had relatively higher rates of hepatitis $B$ seroprevalence compared with children, highlighting the need to strengthen vaccination services targeting adults. In Turkey, hepatitis B vaccines are provided free of charge to individuals at high-risk for contracting the virus. It is therefore important to assess individuals at every opportunity at consultations in primary care and to offer vaccination for high-risk groups. It is important to remember that both patients and healthcare providers can be reluctant to report high-risk sexual practices, particularly in traditional societies. Information should therefore be provided about the risk factors for contracting hepatitis $B$ infection and benefits of vaccination [26].

Data stratified by sex indicated that notification rates were comparable until adulthood. From the age of 20 years, however, rate differences between men and women increased. In the age group 30-44 years, the rate difference was 3.3 per 100,000. Seroepidemiological studies carried out in different parts of Turkey among adults also show higher rates of $\mathrm{HBsAg}$ positivity among men $[5,9,21,27,28]$. Sex differences suggest a higher rate of exposure to risk factors among men. Unfortunately in Turkey, routes of transmission are not reported for notified cases, but we can consider several reasons for men to predominantly contract the infection. High-risk behaviours such as having multiple sexual partners, male homosexual contact, using intravenous drugs, or sharing contaminated blades in barber shops may be more prevalent among men $[6,29]$. High-risk groups, particularly males, should be asked about potential exposure and offered vaccination at every opportunity.

Notification rates differed by geographical region, with the highest rates identified in Istanbul, western Marmara, the Black Sea and middle Anatolia. We need to be cautious in comparing these rates because access to healthcare, diagnostic capacity and notification rates may vary widely. Seroepidemiological studies show that residents of eastern, particularly south-eastern, Anatolia have higher rates of $\mathrm{HBsAg}$ positivity compared to the other regions $[6,10,11]$. Also the meta-analysis carried out by Toy et al. which evaluated studies published between 1999 and 2009, identified the highest rates in the eastern parts of Turkey [5]. Our results for south-eastern Anatolia could therefore be an underestimation and may be related to low access to healthcare, underdiagnosis and/or notification practices. Eastern parts are the least developed regions in Turkey. So we expect there a higher rate of underestimation than in the other regions. Efforts 
should be made to understand the regional differences and eliminate their causes.

In 2008 and 2012, notification rates for acute hepatitis B in Turkey were 8.0 and 3.6 per 100,000, respectively. In Europe (among 27 European Union Member States and three European Economic Area countries), the notification rate of acute hepatitis $B$ was 0.8 per 100,000 in 2010 [30]. Among the countries reporting acute cases, the Czech Republic (2.3 per 100,000), Romania (2.3 per 100,000) and Lithuania (2.1 per 100,000) had the highest notification rates [30]. The rates notified from Turkey were higher than in other European countries, although direct comparison between countries is not possible, due to differences in surveillance systems. It is hard to predict the level of underestimation and project the actual rates. However, a study conducted in one Turkish city in 2003 provides a clue on the rate of underestimation: Durusoy and Karababa compared data obtained from serology laboratories with the notifications received by the Provincial Health Directorate in order to understand the completeness of acute hepatitis B notifications in 2003 in Izmir, the third largest city in Turkey located in the west near the Aegean coast. At that time, the notification rate of acute hepatitis $B$ in Izmir was 6.4 per 100,000 . Yet by capture-recapture analyses, the authors calculated the notification rate as 52.2 per 100,000 (95\% confidence interval: $39.9-$ 64.5 per 100,000) [31].

The reported rates therefore suggest an underestimation. However, secular trends indicate that the rates are declining. With the available data, it is not possible to determine the quantitative impact of each preventive measure on notification rates. Although it is possible to assume that all measures had interacted synergistically, the trend among the younger age groups highlighted in particular the importance of universal vaccination and catch-up strategies. The impact of infant and school vaccination on acute hepatitis $B$ notification rates had been demonstrated in a number of studies [23,32-34]. Still, vaccination can only partly explain the decline in hepatitis $B$ infections among children. Since horizontal transmission is an important route particularly among groups with low socioeconomic status, improved living conditions, interrupting the horizontal transmission, may have contributed to the downward trend.

\section{Conclusion}

Secular trends reveal that the notification of acute hepatitis B is decreasing in all age groups in Turkey. High vaccination coverage and catch-up strategies had a positive impact among young age groups. Although a decreasing trend was achieved for adults after $\mathbf{2 0 0 5}$, these rates remain high and demand strengthened prevention measures targeting adults, particularly men.
${ }^{\star}$ Erratum:

The correct illustration for Figure 1 was uploaded on 25 November 2013.

\section{References}

1. World Health Organization (WHO). Hepatitis B. Fact Sheet 204. Geneva: WHO; 2000. Available from: http://who.int/inf-fs/en/ fact204.html

2. Hepatitis B vaccines. Wkly Epidemiol Rec. 2004;79(28):255-63. PMid:15344666.

3. The Global Alliance for Vaccines and Immunizations (GAVI). Hepatitis B Fact Sheet. Geneva: GAVI; 2005.

4. Değertekin $H$, Güneş $G$. Horizontal transmission of hepatitis $B$ virus in Turkey. Public Health. 2008;122(12):1315-7. http://dx.doi.org/10.1016/j.puhe.2008.04.010 PMid:18752817

5. Toy M, Önder FO, Wörmann T, Bozdayi AM, Schalm SW, Borsboom GJ, et al. Age- and region-specific hepatitis B prevalence in Turkey estimated using generalized linear mixed models: a systematic review. BMC Infect Dis. 2011;11:337. http://dx.doi.org/10.1186/1471-2334-11-337 PMid:22151620 PMCid:PMC3262158

6. Mehmet D, Meliksah E, Serif Y, Gunay S, Tuncer O, Zeynep S. Prevalence of hepatitis $B$ infection in the southeastern region of Turkey: comparison of risk factors for HBV infection in rural and urban areas. Jpn J Infect Dis. 2005;58(1):15-9. PMid:15728984

7. Yildirim B, Barut S, Bulut Y, Yenişehirli G, Ozdemir M, Cetin I, et al. Seroprevalence of hepatitis $B$ and $C$ viruses in the province of Tokat in the Black Sea region of Turkey: A population-based study. Turk J Gastroenterol. 2009;20(1):27-30. PMid:19330732

8. Karabay O, Serin E, Tamer A, Gökdoğan F, Alpteker H, Ozcan $A$, et al. Hepatitis B carriage and Brucella seroprevalence in urban and rural areas of Bolu province of Turkey: a prospective epidemiologic study. Turk J Gastroenterol. 2004;15(1):11-3. PMid:15264115

9. Akcam FZ, Uskun E, Avsar K, Songur Y. Hepatitis B virus and hepatitis $C$ virus seroprevalence in rural areas of the southwestern region of Turkey. Int J Infect Dis. 2009;13(2):27484.

http://dx.doi.org/10.1016/j.ijid.2008.07.005 PMid:18945630

10. Değertekin H, Tuzcu A, Yalçin K. Horizontal transmission of HBV infection among students in Turkey. Public Health. 2000;114(5):411-2. PMid:11035467

11. Kanra G, Tezcan S, Badur S, Turkish National Study Team. Hepatitis B and measles seroprevalence among Turkish children. Turk J Pediatr. 2005;47(2):105-10. PMid:16052847

12. Otkun M, Erdogan MS, Tatman-Otkun M, Akata F. Exposure time to hepatitis $B$ virus and associated risk factors among children in Edirne, Turkey. Epidemiol Infect. 2005;133(3):50916.

http://dx.doi.org/10.1017/So950268805003675 PMid:15962558 PMCid:PMC2870275

13. Badur S. Hepatit B infeksiyonları: Epidemiyoloji ve Aşı [Hepatitis B Infections: Epidemiology and Vaccine]. Klinik Gelişim. 2005;18(3):32-43.Turkish.

14. Ertekin V, Selimoğlu MA, Altinkaynak S. Sero-epidemiology of hepatitis $B$ infection in an urban paediatric population in Turkey. Public Health. 2003;117(1):49-53. http://dx.doi.org/10.1016/S0033-3506(02)00018-5

15. Doganci T, Uysal G, Kir T, Bakirtas A, Kuyucu N, Doganci L. Horizontal transmission of hepatitis $B$ virus in children with chronic hepatitis B. World J Gastroenterol. 2005;11(3):418-20. PMid:15637758

16. Ucmak H, Kokoglu OF, Celik M, Ergun UGO. Intra-familial spread of hepatitis B virus infection in eastern Turkey. Epidemiol Infect. 2007;135(8):1338-43. http://dx.doi.org/10.1017/S0950268807008011 PMid:17313693 PMCid:PMC 2870700

17. General Directorate for Primary Health Care. Bulaşıcı Hastalıkların İhbarı ve Bildirim Sistemi: Standart Tanı, Sürveyans ve Bildirim Sistemi. [Standard Diagnosis, Surveillance and Laboratory Guideline for Communicable Diseases' Notification and Reporting System]. Ankara: Turkish Ministry of Health; 2004. Turkish.

18. Classification Sever. Ankara: TUIK Turkish Statistica Institute. [Accessed: 1 Sep 2012] Available from: http:// 
tuikapp.tuik.gov.tr/DIESS/SiniflamaSurumDetayAction. do? surumld=164\&turld=7\&turAdi $=5$. Geographical Classifications

19. Bulaşıcı Hastalıkların Bildirim Sistemi Yönergesi. 24.02.2004 tarih ve 1534 sayılı [Communicable disease notification system directive. No. 1534]. Ankara: Ministry of Health; 24 Feb 2004. Turkish. Available from: http://www.saglik.gov.tr/TR/ belge/1-4005/bulasici-hastaliklarin-ihbari-ve-bildirim-sistemiyoner-.html

20. Bulaşıcı Hastalıkların İhbarı ve Bildirim Sistemi Genelgesi 22.10.2004 tarih ve 129 sayılı [Communicable Disease Notification System Circular. No. 129]. Ankara: Ministry of Health; 22 Oct 2004. Turkish. Available from: https:// www.google.com.tr/url?sa $=\mathrm{t} \& \mathrm{rct}=\mathrm{j} \& \mathrm{q}=\& \mathrm{esrc}=\mathrm{s} \& \mathrm{so}$ urce $=$ web \&cd $=1 \&$ ved $=0$ CCsQFjAA\&url $=h t t p \% 3 A \% 2$ F\%2Fwww.saglik.gov.tr\%2FASHGM\%2Fdosya\%2F1$12244 \% 2 \mathrm{Fh} \% 2$ Fbulasicihbargenelge.doc\&ei=kbmIUqmtE8_Ks wb454DQCg\&usg=AFQjCNE3WzQXP5QY9WK6g_4OBwZTboBW ig

21. Erden S, Büyüköztürk S, Calangu S, Yilmaz G, Palanduz $S$, Badur S. A study of serological markers of hepatitis B and C viruses in Istanbul, Turkey. Med Princ Pract. 2003;12(3):184-8. http://dx.doi.org/10.1159/000070757

PMid:12766338

22. Stroffolini T, Mele A, Tosti ME, Gallo G, Balocchini E, Ragni P, et al. The impact of the hepatitis B mass immunisation campaign on the notification and risk factors of acute hepatitis B in Italy. J Hepatol. 2000;33(6):980-5. http://dx.doi.org/10.1016/S0168-8278(0o)80132-4

23. Mele A, Tosti ME, Mariano A, Pizzuti R, Ferro A, Borrini B, et al. Acute hepatitis B 14 years after the implementation of universal vaccination in Italy: areas of improvement and emerging challenges. Clin Infect Dis. 2008;46(6):868-75. http://dx.doi.org/10.1086/528687 PMid:18269332

24. La Torre G, Nicolotti N, de Waure C, Chiaradia G, Specchia ML, Mannocci A, et al. An assessment of the effect of hepatitis $B$ vaccine in decreasing the amount of hepatitis $B$ disease in Italy. Virol J. 2008;5:84.

http://dx.doi.org/10.1186/1743-422X-5-84

PMid:18652653 PMCid:PMC2517063

25. D’Argenio P, Esposito D, Mele A, Ortolani G, Adamo B, Rapicetta $M$, et al. Decline in the exposure to hepatitis $A$ and $B$ infections in children in Naples, Italy. Public Health. 1989;103(5):385-9. http://dx.doi.org/10.1016/S0033-3506(89)80009-5

26. Mast EE, Weinbaum CM, Fiore AE, Alter MJ, Bell BP, Finelli L, et al. A comprehensive immunization strategy to eliminate transmission of hepatitis B virus infection in the United States: recommendations of the Advisory Committee on Immunization Practices (ACIP) Part II: immunization of adults. MMWR Recomm Rep. 2006;55(RR-16):1-33. PMid:17159833

27. Demirtürk N, Demirdal T, Toprak D, Altindis M, Aktepe OC. Hepatitis $B$ and $C$ virus in West-Central Turkey: seroprevalence in healthy individuals admitted to a university hospital for routine health checks. Turk J Gastroenterol. 2006;17(4):267-72. PMid:17205404

28. Emiroglu $\mathrm{HH}$, Altunay $\mathrm{H}$, Oguz S. Prevalence of hepatitis $\mathrm{B}$ virus carriers among soldiers and civilians in Turkey. J Clin Gastroenterol. 2004;38(7):614-5. http://dx.doi.org/10.1097/00004836-200408000-00018 PMid:15232371

29. Khan F, Shams S, Qureshi ID, Israr M, Khan H, Sarwar MT, et al. Hepatitis $B$ virus infection among different sex and age groups in Pakistani Punjab. Virol J. 2011;8:225

http://dx.doi.org/10.1186/1743-422X-8-225

PMid:21569532 PMCid:PMC3118204

30. European Centre for Disease Prevention and Control (ECDC). Annual Epidemiological Report 2012. Reporting on 2010 surveillance data and 2011 epidemic intelligence data. Stockholm: ECDC; 2013. Available from: http://ecdc.europa. eu/en/publications/_layouts/forms/Publication_DispForm. aspx?ID =753\&List=4f55ad51-4aed-4d32-b960-aff70113dbb9o

31. Durusoy R, Karababa AO. Completeness of hepatitis, brucellosis, syphilis, measles and HIV/AIDS surveillance in Izmir, Turkey. BMC Public Health. 2010;10:71.

http://dx.doi.org/10.1186/1471-2458-10-71

PMid:20158922 PMCid:PMC 2834629

32. Pitigoi D, Rafila A, Pistol A, Arama V, Molagic V, Streinu-Cercel A. Trends in hepatitis B notification in Romania, 1989-2005. Euro Surveill. 2008;13(2):pii=8012. Available from: http:// www.eurosurveillance.org/ViewArticle.aspx?Articleld=8012. PMid:18445385

33. Salleras L, Dominguez A, Bruguera M, Carde-osa N, Batalla J, Carmona G, et al. Dramatic decline in acute hepatitis B infection and disease notification rates among adolescents and young people after 12 years of a mass hepatitis B vaccination programme of pre-adolescents in the schools of Catalonia (Spain). Vaccine. 2005;23(17-18):2181-4. http://dx.doi.org/10.1016/j.vaccine.2005.01.068 PMid:15755591

34. Hong Z, Smart G, Zaniewski G, Wu H, Wu J, Goedhuis N, et al. Epidemiological study of hepatitis $B$ virus infection in Manitoba, Canada, 1992-2003. Eur J ClinMicrobiol Infect Dis. 2005;24(7):464-70.

http://dx.doi.org/10.1007/s10096-005-1350-6 PMid:15959814 